\title{
Improving Teachers' Ability In Using Whatshapp Voice Note Facilities As A Media For Distance Learning Through Integrated Guidance Activities At Sd Borosuci Kapanewon Kalibawang Kabupatenkulon Progo Academic Year 2020/2021
}

\author{
Suprihatin ${ }^{a, *}$ \\ a SD Negeri Borosuci Kalibawang Kabupaten Kulon Progo \\ *Corresponding author: atin-suradi@yahoo.co.id
}

Received: August 29, 2021; Accepted: October 4, 2021; Published: October 15, 2021

\begin{abstract}
This study aims to determine and describe the teacher's ability to use the WhatsApp Voice Note application program in the distance learning process through integrated mentoring. The sample in this study was 9 teachers consisting of 6 classroom teachers and 3 subject teachers who were selected based on criteria using the WhatsApp Voice Note application program. This research was conducted in 2 cycles. Each cycle consists of 2 meetings and research procedures include; planning, implementation, observation and reflection. Meanwhile, to find out the teacher's activities at work, the researchers completed measuring instruments with observation instruments based on their ability to use the WhatsApp Voice Note application. The next aspect observed was the implementation of mentoring activities for researchers (principals). The results of the first cycle of research on the teacher's ability to use WhatsApp Voice Notes in Distance Learning obtained the lowest average score of the first cycle of $70.86 \%$, the conversion value of 3 , the "Good" category the highest average score of $77.55 \%$, the conversion value; 3 , category "Good". The lowest average score in cycle II; $86.86 \%$, value conversion; 4, "Very Good" category, the highest average score; $91.30 \%$, value conversion; 4, "Very Good" category. As for the increase in the results of the first cycle to the second cycle; $13.75 \%$. Furthermore, the results of the research cycle I the average score based on the percentage obtained the lowest average score of $82.04 \%$, the conversion value was 3 , the category "Satisfactory" while the highest average score reached $87.89 \%$, the conversion value was 4 , the category "Very Satisfactory" cycle II obtained the lowest average score of $89.72 \%$, conversion value of 4 , category "Very Satisfactory" the highest average score of $94.63 \%$, conversion value of 4 , category "Very Satisfactory". The results of the research cycle I and II there was an increase of $6.74 \%$. The results of interviews with participants and researchers related to the implementation of the guidance program are contained in the interview transcript table for the WhatsApp Voice Note application program material considering that during the pandemic it was not only SD Negeri Borosuci Kalibawang that experienced difficulties, but every elementary school in the Kulon Progo Regency area. Research through integrative guidance is very helpful for teachers to add new knowledge about the WhatsApp Voice Note application. Furthermore, the principal also feels that it provides new experiences and is helped by all teachers who have a passion for learning to do distance learning in the era of the covid-19 pandemic.
\end{abstract}

Keywords: WhatsApp Voice Note, Distance Learning, Integrated Guidance

\section{INTRODUCTION}

Distance learning is the only option in the midst of the Covid-19 pandemic. Based on the Circular of the Minister of Education and Culture Number 4 of 2021 concerning the implementation of education policies in the emergency period of the spread of the corona virus disease (Covid-19), it is necessary to 
carry out the learning process from home through online learning. The online distance learning system (on the network) is a learning system without face to face directly between teachers and students carried out online using the internet network.

Distance learning is carried out using several choices of facilities, namely WhatsApp, Google Meet, Zoom meetings and Google Classroom. This facility was chosen because it can be used according to the needs of its users. WhatsApp can send text messages, voice and video messages, various kinds of images/photos, videos, learning material documents and more. Google Classroom has the same function as WhatsApp but the facility is usually used for discussions and sending assignments to make it easier and neater, while the Google Meet and Zoom facilities are for face-to-face online meetings so that teachers can see the faces of their students who pay attention to the teacher when explaining material.

WhatsApp is an application with a very large number of users. WhatsApp is the most widely used facility related to teacher, student and parent communication so that students do not experience much difficulty in participating in distance learning provided by teachers through this WhatsApp facility compared to using other facilities. However, the use of WhatsApp as an online learning medium is less effective in achieving learning objectives. This is due to various factors, including the lack of a comprehensive and simple explanation from the teacher, the low affective and psychomotor aspects of learning, internet signals, parents' busyness and parents' educational background.

Based on the results of observations made at SD Borosuci Kapanewon Kalibawang, Kulon Progo Regency for the Academic Year 2021/2021, there are at least two challenges of distance learning, namely not all teachers can use facilities related to technology and not all students have communication tools even those who already have have not been able to use and operate the programs contained in mobile devices. To overcome these problems, teachers use the WhatsApp voice note facility as a learning medium for students at the elementary school level. Through WhatsApp teachers can send pictures and videos.

From the results of initial observations made by researchers that the majority of teachers at SD Negeri Borosuci Kalibawang have not mastered technology and information so that during the Covid-19 pandemic they experienced difficulties in distance learning, initial observations obtained data from 9 teachers there were 2 people who were able to use the application program. Voice Note WhatsApp 22.20\%, while 7 teachers still have not mastered the Voice Note WhatsApp application program $77.80 \%$, it can be concluded that through integrated guidance the use of the Voice Note WhatsApp application program at SD Negeri Borosuci Kalibawang teachers is expected to increase their knowledge and skills teacher in using the WhatsApp Voice Note application program. From the observations, the researchers concluded that they took corrective steps through action research to improve the teacher's ability to use the WhatsApp Voice Note application at SD Negeri Borosuci Kalibawang.

Teaching skills are a number of teacher competencies that display their performance in a professional manner. This ability shows how the teacher shows his behavior during interactions in learning [1]. The ability of teachers as a description of the qualitative nature of the behavior of teachers or education personnel that looks very meaningful [2].

Learning media are everything that can be used as a tool in order to support efforts to implement the teaching and learning process that leads to the achievement of learning objectives. E-Learning allows students to gain knowledge without having to physically attend class. Learners can be at home, while the "instructor" and the lessons being followed are elsewhere, and it can be in another city or even in another country. Interactions can be run on-line and real-time or off-line or archived [3].

The Covid-19 pandemic requires educators to carry out learning with a learning approach that in its implementation does not meet face-to-face in learning. Learning usually uses internet-based media. WhatsApp is an internet-based facility that allows each user to share various kinds of content according to the supporting features. The WhatsApp media functions that can be used include being able to send messages, chat groups, share photos, videos, and documents. In distance learning content, it is very useful and easily recognizable by elementary school students to receive subject matter, assignments and practice questions [4].

The benefits provided by the WhatsApp Messenger Group facility are a means of effective learning discussions, while the benefits of the features displayed in learning are providing collaborative and collaborative online learning facilities between teachers and students, free of charge that is easy to use. can be used to share comments, posts, pictures, videos, sounds, and documents. makes it easy to disseminate announcements and publish works in groups, and can be easily created and disseminated through various features of WhatsApp Messenger Group [5]. 
Voice note is one feature that is quite helpful in conditions of not being able to type messages. Unlike voice calls, voice notes are often used to send short messages when typing is not possible. The instant messaging facility WhatsApp allows users to send voice messages or Voice Notes easily. With this feature, users do not need to type messages to be sent to other users or in group conversations. This feature can be used to convey important or sensitive information. In other words, voice note is a chat facility using the voice message feature (voice note). Someone can have a conversation via voice messages that are recorded and delivered to the person we are addressing, then stored in the chat history.

Integrative guidance is integrated guidance means observing, supervising or guiding activities carried out by people with the intention of making improvements. Educational guidance is an effort to coordinate and guide the continuous growth of teachers in schools in the teaching aspect [6]. Educational guidance is an effort to improve teaching as a step for teacher professional growth that is integrated with individual needs with educational goals and main school tasks [7].

Based on the above background, the purpose of this study is to find out whether integrated guidance using Voice Note media can improve the ability of teachers in distance learning and to describe the steps of integrated mentoring using Whasapp Voice Note media can improve the ability of school principals in learning long distance.

\section{RESEARCH METHODS}

This research takes the form of school action research, namely improving teacher performance using WhatsApp voice note facilities as a distance learning medium in order to improve the teaching and learning process which consists of III cycles and each cycle consists of 4 stages, namely: (1) program planning stage action, (2) implementation of the action program, (3) program observation, (4) reflection.

The subjects in this study were teachers of SD Negeri Borosuci which consisted of 8 civil servant teachers and 1 non-permanent teacher. The object of this research is how to improve teaching and learning activities carried out by teachers by using voice note whattsap facilities as distance learning media through integrated guidance at SD Negeri Borosuci, Kalibawang. Research Time The author's research was carried out for 3 months starting January 4 to March 28, 2021.

This research is a process of reviewing a cyclical system. This procedure includes the following stages: (1) planning, (2) implementation, (3) observation, and (4) reflection. The four activities are interrelated and sequentially form a cycle. School Action Research is cyclical research, meaning that research is carried out repeatedly and continuously until the research objectives can be achieved [8]. The classroom Action Research Flow can be seen in Figure 1.

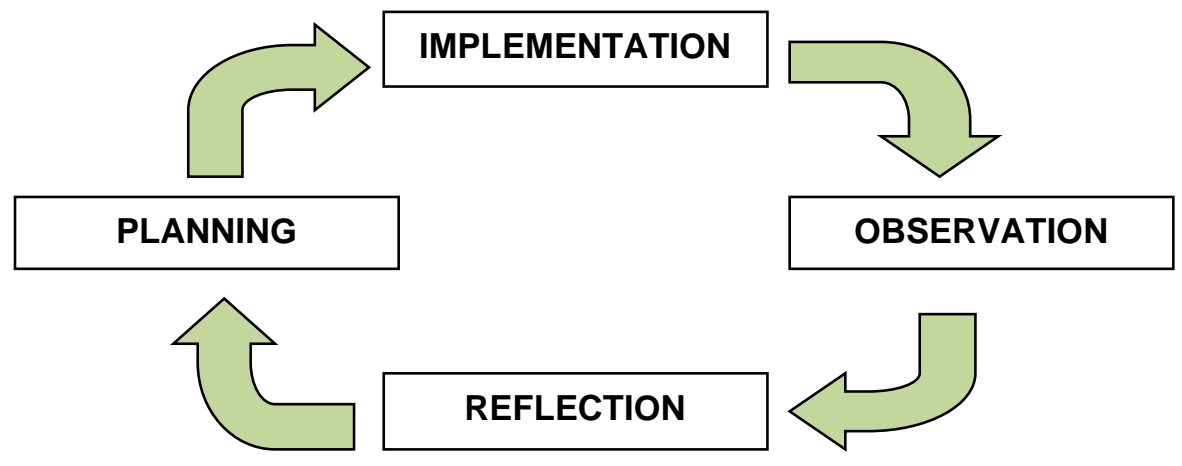

Figure 1. Classroom Action Research Flow

Data collection techniques were carried out by participating in observation (Participant Observation), in-depth interviews, and documentation of students at SD Negeri Borosuci Kapanewon Kalibawang Kulon Progo to overcome learning in the Covid-19 pandemic era

The data analysis technique used a qualitative descriptive technique. The data obtained in the study were obtained from the results of the observation sheets for teachers and resource persons (principals) in the integrated mentoring process through the use of the WhatsApp voice note facility. The 
results of filling in the principal teacher's observation sheet in mentoring activities before and after mentoring, recapitulation of observations before and after mentoring, results between cycles I and II, each cycle consisting of meetings 1 and 2, and if the research is not successful, it will be continued on the third cycle meeting, the analysis used the average of the observations, the percentage of the average score, the value conversion $(0 \%<X 44 \%=1 ; 45 \%<X 64 \%=2 ; 65 \%<X 84 \%=3$; and $85 \%<X 100 \%=4)$, then the results are determined by category, then tabulated and described for each instrument. This descriptive analysis is used to describe the characteristics of the research data and answer the problems listed in the problem formulation.

The results of the observation of activities related to the ability of participants in the integrated mentoring of SD Negeri Borosuci Kalibawang teachers include cycles I, II and III supervision/monitoring cycles consisting of 9 aspects, consisting of 31 indicators, each indicator being given a minimum score of 1 , and a maximum of 4, and given category; Very good, Good, Fairly good, and Not very good. then analyzed descriptively quantitatively based on the monitoring scoring guidelines for cycle I and monitoring scoring guidelines for cycle II that have been made by researchers. The scoring guidelines for Cycle I monitoring and Cycle II monitoring are as follows:

$$
\text { Average value }=\frac{J S}{S M} \times 100 \%
$$

Information:

1. JS: The average number of scores obtained

2. SM: Maximum score

The observations made by the guidance participants are related to the implementation of integrated guidance using observation instruments covering 4 aspects and 16 indicators, each indicator being given a minimum score of 1 and a maximum score of 4 while the results of the assessment are categorized as very satisfactory, satisfactory, unsatisfactory and unsatisfactory. Then the results are analyzed first and then described.

Interviews from the research were obtained through interviews with mentored participants and interviews with the principal as a researcher. The results of interviews with teachers were analyzed descriptively to complete the results of the teacher's activity observation sheet and the researcher's activity observation sheet. Interviews need to be conducted to complete the required data. This is useful for reflecting and revising for the next cycle.

\section{RESULTS AND DISCUSSION}

Based on the results of the research that the researchers have done, it can be seen that the use of the WhatsApp Voice Note application program through integrated guidance carried out by the principal as a researcher at the Borosuci Kalibawang State Elementary School aims to improve the quality of teachers in conducting distance learning in the era of the covid-19 pandemic. The results of the first and second cycles of the teacher's ability to use the WhatsApp Voice Note application program are listed in Table 1.

Table 1. Results of Participants' Ability to Use WhatsApp Voice Notes in Distance Learning through Integrated Guidance Cycles I and II for teachers at SD Negeri Borosuci Kalibawang

\begin{tabular}{ccccccccccc}
\hline & & \multicolumn{7}{c}{ Earning Average Score (\%) } \\
\cline { 3 - 10 } No & Activity & Gk I & GK II & GK III & Gk IV & GK V & Gk VI & Gr PAI & Gr PAK & $\begin{array}{c}\text { GR } \\
\text { PJOK }\end{array}$ \\
\hline \multirow{2}{*}{ A } & Cycles I & 75,63 & 72,46 & 73,10 & 73,45 & 70,86 & 77,55 & 72,64 & 72,41 & 72,82 \\
B & Cycles II & 89,79 & 89,52 & 90,21 & 87,32 & 88,20 & 91,30 & 89,24 & 86,86 & 89,01 \\
\hline
\end{tabular}

The results of the first cycle of research related to the teacher's ability to use Voice Note WhatsApp in Distance Learning after following the mentoring obtained the lowest average score of the first cycle of $70.86 \%$, the conversion value of 3, the "Good" category while the highest average score was $77.55 \%$, value conversion; 3, category "Good". While the acquisition of the lowest average score in cycle II; $86.86 \%$, value conversion; 4, "Very Good" category, and the highest average score reached; $91.30 \%$, value conversion; 4, "Very Good" category. Meanwhile, if it is seen that there is an increase in the results of the 
first cycle to the second cycle, it reaches; $13.75 \%$. Shows that the integrative guidance in the use of the WhatsApp Voice Note program that has been carried out by researchers has a positive impact on the teacher's ability to carry out the distance learning process.

Action research through an integrated guidance process carried out by researchers showed a very satisfactory development when viewed from the results of observations carried out in collaboration with the mentoring participants. The results of the research related to the implementation of integrated guidance on the use of the WhatsApp Voice Note application cycle I and II, the teachers of SD Negeri Borosuci Kalibawang can be seen based on Table 2.

Table 2. Competence of Researchers Presenting Using Voice Note WhatsApp in Distance Learning through Integrated Guidance Cycles I and II for teachers at SD Negeri Borosuci Kalibawang

\begin{tabular}{ccccccccccc}
\hline & & \multicolumn{8}{c}{ Earning Average Score (\%) } \\
\cline { 3 - 10 } No & Activity & Gk I & GK II & GK III & Gk IV & GK V & Gk VI & Gr PAI & $\begin{array}{c}\text { Gr } \\
\text { PAK }\end{array}$ & $\begin{array}{c}\text { GR } \\
\text { PJOK }\end{array}$ \\
\hline 1 & Cycles I & 87,89 & 82,39 & 83,86 & 86,66 & 84,71 & 87,86 & 84,44 & 84,61 & 82,04 \\
2 & Cycles II & 91,74 & 92,52 & 94,63 & 92,25 & 92,94 & 93,56 & 90,37 & 89,72 & 92,78 \\
\hline
\end{tabular}

The results of the research cycle I the average score based on the percentage obtained the lowest average score reached $82.04 \%$, the conversion value was 3, with the "Satisfactory" category while the highest average score reached $87.89 \%$, the conversion value was 4 , with the category "Very Satisfactory" while the second cycle obtained the lowest average score reaching $89.72 \%$, conversion value 4, category "Very Satisfactory" while the highest average score reaching $94.63 \%$, conversion value 4 , with the category "Very Satisfactory" " The results of the research cycle I and II there is an increase of $6.74 \%$.

The results of the research above that the mentoring process for teachers is very important considering that not all teachers have the same ability in mastering application programs found on cellphones or other devices so that guidance is needed. Teaching and learning activities will never run without a teacher [9]. Referring to this role, learning outcomes and learning progress to be achieved by students are strongly influenced and determined by the pattern of relationships between teachers and students [10].

The results of the study which consisted of the ability of participants to use the Voice Note WhatsApp application program and the ability of researchers to present material about integrated mentoring to participants at SD Negeri Borosuci Kalibawang, researchers also conducted interviews with participants and researchers related to the implementation of the guidance program whose results are written in the table The transcript of the interview above, in which the participants are very enthusiastic about the guidance of the WhatsApp Voice Note application program material, considering that during the pandemic, it was not only the SD Negeri Borosuci Kalibawang which experienced difficulties in almost every elementary school in the Kulon Progo Regency area. Research through integrative guidance is very helpful for teachers and can add new knowledge about information technology. Thus, through integrative guidance, the WhatsApp Voice Note application program can increase the ability of teachers to conduct distance learning in the era of the Covid-19 pandemic.

\section{CONCLUSION}

The results of the first cycle of research related to the teacher's ability to use WhatsApp Voice Notes in Distance Learning after attending the mentoring obtained the lowest average score of the first cycle of $70.86 \%$, the conversion value of 3, the "Good" category while the highest average score was 77 , $55 \%$, value conversion; 3 , category "Good". While the acquisition of the lowest average score in cycle II; $86.86 \%$, value conversion; 4, "Very Good" category, and the highest average score reached; $91.30 \%$, value conversion; 4, "Very Good" category. Meanwhile, if it is seen that there is an increase in the results of the first cycle to the second cycle; $13.75 \%$. And then the results of the first cycle of research, the average score based on the percentage obtained the lowest average score of $82.04 \%$, the conversion value was 3 , the category "Satisfactory" while the highest average score was $87.89 \%$, the conversion value was 4 , the category "Very Satisfactory" while the second cycle obtained the lowest average score of $89.72 \%$, conversion value of 4 , category "Very Satisfactory" while the highest average score of $94.63 \%$, conversion 
value of 4, category "Very Satisfactory". The results of the research cycle I and II there was an increase of $6.74 \%$.

\section{REFERENCES}

1. Kunandar, Guru Profesional Implementasi KTSP dan Sukses dalam Sertifikasi Guru, (Grafindo Persada, Jakarta, 2008).

2. C. Wijaya, Kemampuan Dasar Guru dalam Proses Belajar Mengajar, (Remaja Rosdakarya, Bandung, 1991)

3. N. Suryani dan L. Agung, Strategi Belajar Mengajar, (Ombak, Yogyakarta, 2012)

4. Jumiatmoko, Whatsapp Messenger Dalam Tinjauan Manfaat Dan Adab. Wahana Akademika, 3, 1, (2016)

5. C. Barhomi, Effectiveness of WhatsApp Mobile Learning Activities Guided by Activity eory on Students Knowledge Mangement, Contemporary Educational Technology, 6, 3, 221-238. (2015)

6. Mukhtar dan Iskandar, Orientasi Baru Supervisi Pendidikan, (Gaung Persada Press, Jakarta, 2009)

7. S. Sagala. Supervisi Pembelajaran dalam Profesi Pendidikan. (Alfabeta, Bandung, 2010)

8. A, Suharsimi. Prosedur Penelitian Suatu Pendekatan Praktek, (Rineka Cipta, Jakarta, 2005)

9. R.L., Gibson, dan M.H. Mitchell, Bimbingan dan Konseling, Edisi Ketujuh. (Pustaka Pelajar, Yogyakarta 2011)

10. Sukmadinata. Metode Penenelitian Pendidikan. (PT Remaja Rosdakarya, Bandung, 2010) 